\title{
Study on the Influence of Litigation Risk on Chinese Listed Companies
}

\author{
Ci Zhang ${ }^{1, *}$ \\ ${ }^{1}$ Macau University of Science and Technology, Macau, China \\ "Corresponding author. Email: 277641088@qq.com

\begin{abstract}
In recent years, the number of lawsuits filed by Chinese listed companies has been on the rise. So does the scale of the amount involved. When a public company is involved in litigation, the potential uncertainty increases dramatically, threatening investment projects including innovation. This paper discusses the evolution of litigation risk, the factors affecting litigation risk and the impact of litigation risk on enterprise innovation. Results show that once the company is involved in lawsuit, it will face huge labor costs, litigation costs, as well as the compensation resulting from loss of the lawsuit, which seriously undermines its financial situation. Once cash flows tighten, management will cut non-rigid investment projects, such as research and development activities, to bring risks under control.
\end{abstract}

Keywords: law and finance, litigation risk, enterprise innovation, China's listed companies, adverse selection

\section{INTRODUCTION}

China's reform and opening up has created a miracle that has changed China's influence on the world. The unremitting efforts of more than 40 years have not only improved the living standard of the Chinese people, but also witnessed the rapid development of China's economy. In order to ensure the healthy development of China's market-oriented economic reform, the construction of the legal system has been continuously optimized and improved. The legal awareness of residents and enterprises has also been improved, and more and more people choose to solve their disputes through legal means. From 1991 to 2018, the number of lawsuits involving listed companies continued to increase, and the amount involved also showed a trend of substantial increase. Thus it can be seen that the litigation risk faced by enterprises has become one of the important factors affecting their normal operation. Uncertainty, such as the risk of potentially huge damages, rises sharply for firms that may face litigation. The higher the litigation risk, the greater the impact on the normal operation of the enterprise. The more cases involved in enterprises, the more damage will be done to the reputation and image of enterprises, which will inevitably reduce the interest of some investors, resulting in the failure of enterprise innovation projects due to lack of funds. In some aspects, the amount involved will directly influence the investment decisions of enterprises. If a large amount of money is spent on litigation, some projects with large upfront investment and low return will be ignored. Projects with large upfront investment are likely to face sustained losses in the early stages.

\section{DEVELOPMENT OF LAW AND FINANCE}

Law and finance, a new discipline emerged in the United States in the middle and late 1990s, and formed by the intersection of finance and law, mainly explores such issues as the relationship between law and finance, the efficiency of financial system in allocating resources, the development of corporate finance and the impact of economic growth. In 1998, four scholars from Harvard University and the university of Chicago, La Porta, Lopez-de-Silanes, Shleifer and Vishny (hereinafter referred to as LLSV), published the founding document Law and Finance, which marked the emergence of Law and Finance. The starting point of the research of LLSV (1998) is the relationship between investor protection and finance. They devised a number of indicators, mainly the rights of external shareholders and creditors, the extent to which they were legally protected from within the enterprise (operators and major shareholders), and how effectively the laws were enforced in 49 countries. The publication of this paper has attracted the attention of many scholars. In 2004, Defond elt (2004) et al. made a further study on the discovery of LLSV and put forward a supplementary conclusion. This series of studies also expanded the research scope of corporate governance. Since then, law and finance have gradually attracted the interest of many legal scholars, financial scholars, management scholars and even historians, whose work has greatly promoted the development of law and finance. At present, the research on law and finance in the fields of finance and accounting mainly focuses on the protection of investors, the protection of minority shareholders' rights and interests, and litigation risks. 
As for litigation risk, most scholars mainly start with the influencing factors of litigation and study the civil litigation involved in listed companies.

\section{INFLUENCING FACTORS OF LITIGATION RISK}

The influencing factors of litigation risk are divided into macro factors and micro factors. Research on macro factors includes the legal environment, accounting standards, and law enforcement systems.

First, the legal environment. LLSV $(1997,1998)$, Kim and Skinner (2012) studied the protection degree of stakeholders of listed companies, such as shareholders, creditors and other investors. Wei Feng and Xue Fei (2010) found that after the implementation of the Law of People's Republic of China on Enterprise Bankruptcy and Real Rights Law of People's Republic of China in 2007, China's creditor protection has improved significantly. Secondly, the accounting standards. Palmrose elt (2004) discussed the influence of the type of misstatement in financial statements issued under non-US GAAP on the probability of litigation occurrence and the outcome of litigation. The results showed that the restatement of statements involving core items significantly affected the occurrence and outcome of litigation, while non-core items had no similar effect. Donelson elt (2012) used rule-oriented continuous scores to verify the degree of accounting standards, and found that companies that adopt oriented accounting standards can reduce the probability of corporate litigation. However, this effect is limited to the probability of litigation, and will not affect the outcome of corporate litigation that adopts the accounting standards. Finally, the law enforcement system. Bushman Piotroski (2006) found that the higher the level of investor protection of state-level companies in the public law enforcement system, the stronger the robustness of financial reports of the companies.

The research on micro factors mainly focuses on the company level, such as information disclosure and internal control. The management of the listed company must inform the shareholders of the true and reliable information. If there is any fraud in the process, the shareholders will resort to litigation to solve the disputes and hold the managers accountable. Therefore, there is a close relationship between litigation and information disclosure. The most common information disclosure is earnings management. The problem of earnings management mainly appears in the company's information disclosure. Earnings management has both advantages and disadvantages in the initial public offering of a company. It can beautify the statement to obtain a higher issue price when issuing, but it may also be a potential risk, resulting in litigation after the company goes public, which is not conducive to the issuance of shares. DuCharme elt (2004) found that there was a significant positive correlation between earnings management behavior and litigation risk. Specifically, earnings management is a common behavior of listed companies during their initial public offering, and both corporate performance and market returns would reverse after listing. The risk of litigation will be increased in the case of abnormal earnings management after the company goes public. On the other hand, the internal control of listed companies has always been a focus of attention. Mao Xinshu and Meng Jie (2013) believe that the higher the litigation risk, the lower the quality of internal control. Liu Hui and Zhang Junrui (2018) found that high quality internal control was negatively correlated with pending litigation of listed companies. Government intervention can reduce the inhibition of internal control on pending litigation. In the litigation cases in which the company is the defendant, internal control has a more significant inhibitory effect on the company's litigation.

\section{THE IMPACT OF LITIGATION RISK ON LISTED COMPANIES IN CHINA}

"Governing the market according to law" is the basis for the healthy and rapid development of the capital market. With the continuous improvement of society, laws and regulations, enterprises or residents have more ways to solve disputes through legal means year by year. (Francis, 1994) The author made statistics on the civil litigation cases of all A-share listed companies in Shanghai and Shenzhen from 2009 to 2018. The number of cases involved has shown an upward trend year by year. Among them, in 2018, the total number of cases involved in civil litigation cases reached 3,969,240. As litigation cases continue to increase, litigation risk has become an important external environment for innovative activities. Both the resident and the listed company usually take the lawsuit as the final remedy to solve the dispute. (See "Fig. 1") 
Civil Action Cases

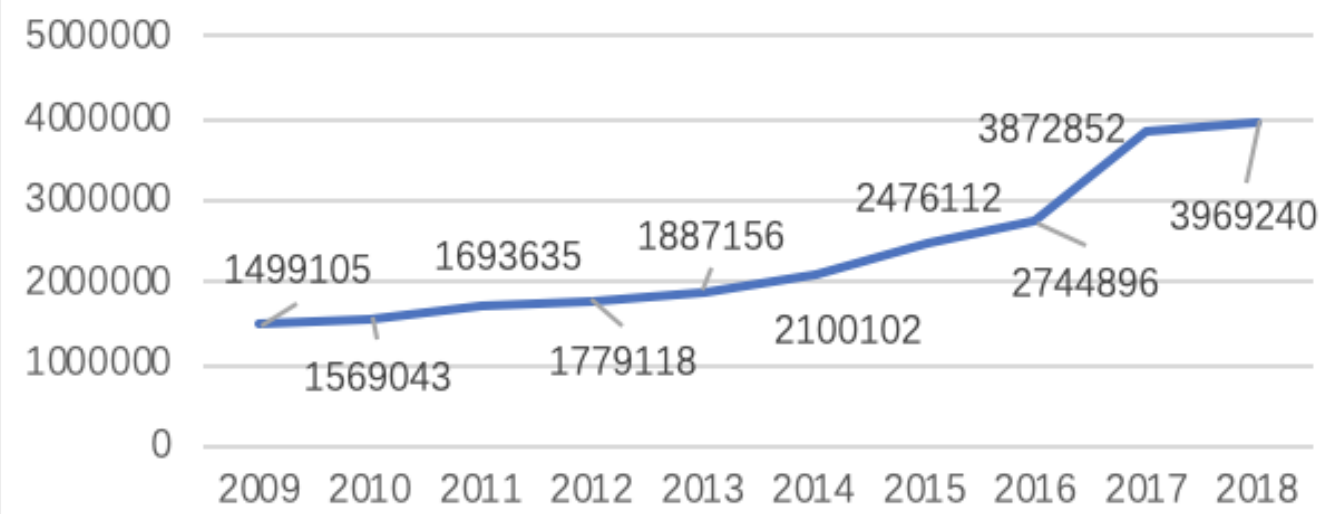

Fig. 1. Civil action cases.

Today, trade frictions between China and the United States are escalating, and the Chinese economy is carrying heavy burdens. Facing the external environment, if China wants to improve its status in the world economy, it must strengthen its core competitiveness through innovation, so as to win the initiative of development. Innovation is the first driving force for development, the first of China's five development concepts, and the main source of competitive advantage for enterprises. In recent years, with the support of the national strategy, China has introduced a series of policies to encourage enterprises to innovate. Thanks to "mass entrepreneurship and innovation", entrepreneurs have a strong sense of innovation, the innovation capacity and innovation investment of enterprises continue to increase, and innovation has increasingly become an important driving force for the development of enterprises. There are many factors that influence innovation, including the state-level social capital stock, national policy, economic development, company-level internal competition in the industry, asset size, operational risk and so on. Enterprise innovation is characterized by high risk, uncertainty, high failure rate, heterogeneity and long cycle (Holmstrom, 1989), so a stable external environment is indispensable. Any changes in the external environment may cause significant impact on innovation activities.

The famous economist George Akerlof proposed the theory of adverse selection in 1970. In his published paper The market for 'Lemons': Quality Uncertainty and the Market Mechanism, he pointed out that the reason for "adverse selection" is the asymmetric information in the market. It is a phenomenon that the two parties in the market transaction do not understand each other's information, which leads to the trading of more and more inferior goods, while the goods of good quality are gradually crowded out of the market. Akerlof took the information asymmetry of secondhand car market as an example to analyze the reasons for adverse selection. Buyers do not know the quality of second-hand cars and are not convinced by the information provided by the sellers. Then the buyers are more inclined to pay a lower price to buy the cars. Therefore, the sellers will only provide the cars with poor quality for their choice, and the good quality second-hand cars will withdraw from the market, which is called adverse selection. As a result, there are only vehicles with poor quality in the second-hand car market, and such a cycle for a long time will result in the inefficiency of the market mechanism.

The theory has been widely used in other fields. For example, in the insurance market, the health status of the policyholder is getting worse and worse, and the insurance price is getting higher and higher. Lenders in the credit markets are getting less creditworthy and borrowing costs are getting higher. There are more and more low-quality job seekers in the labor market. Information asymmetry between exchanges and investors is a common phenomenon in the stock market. The securities themselves have no value, and there is no information of their own. Investors can only analyze whether the securities have investment value based on the information of the capital value of the listed companies they represent. It is difficult for ordinary investors to analyze the listed companies with investment value, so they can only make decisions according to the average situation of the whole market when choosing investment. As a result, high-quality listed companies are reluctant to enter the securities market. 
There is also an adverse selection effect in litigation. Due to the high cost of litigation, people will only take advantage of litigation to protect their interests when they are confident of success, that is, they think they have relatively sufficient information and evidence. As a result, they will choose other ways to resolve controversial cases. This phenomenon is the adverse selection effect in the field of litigation. As a result, when people have no confidence in the judicial process or the judicial cost is high, they will generally choose other solutions in preference. Therefore, the plaintiff who is the prosecutor in the process of litigation usually has a high index of confidence in the judicial approach and a relatively small risk. At present, both the individual and the company generally take the lawsuit as the final relief to solve the dispute. Once the company is involved in the lawsuit, it will face huge labor cost, capital cost, etc., and it is more likely to bear high capital loss and reputation damage, which will lead to liquidity difficulties, destabilize the stable operating environment, and reduce the operating performance and shareholders' equity of the accused enterprise (Bizjak \& Coles, 1995). The innovation activities of a company require a large and long-term capital investment in the early stage to support the longterm research and development activities. The companies involved would then face a sharp rise in uncertainty, which would have a severe impact on their operations, such as high litigation costs, broken relationships with customers, reduced customer stickiness, and large amounts of compensation resulting from losing a lawsuit. This will seriously affect the financial freedom of the company. Once the cash flow becomes tight, the management will consider reducing some non-rigid investment projects, such as R\&D activities, in order to control the overall risk of the company. Even if the adjustment cost of such interruption is higher, the enterprise has to do it in order to operate normally. For listed companies in the hightech industry that rely on R\&D activities to survive, the amount of compensation involved in the case of litigation may not be high. Compensation in patent cases typically ranges from $\$ 10,000$ to $\$ 1$ million, which usually does not have a significant impact on a company's capital. However, once a lawsuit involving infringement of patent rights, copyright or trademark rights is lost, the company's reputation and goodwill, especially its market brand image, will suffer hugely, and thus lose the trust of customers. In addition, the loss of control or right to use the core intellectual property of the product will also hit the market position of the defendant enterprise.

In recent years, China's innovation capacity has been improving year by year. More and more enterprises are developing new technologies and products to enhance their core competitiveness. Innovation has become a hot topic in academia and industry. It is particularly important to improve the core competitiveness of enterprises through innovation activities, and a stable external environment is an important guarantee for the sustainability of enterprises' R\&D activities. As one of the important factors of the external environment, litigation risk should also be widely concerned. The reduction of litigation risk is conducive to the sustainable operation of enterprises and makes the development of enterprises more stable. On the other hand, it can also reduce the capital risk of innovation activities and invest more time cost, human cost and financial cost to enhance innovation activities, so as to develop and strengthen enterprises and thus become the inexhaustible driving force for the sustainable development of the country.

\section{CONCLUSION}

In order to seize the market, consolidate the market position and improve the core competitiveness, enterprises have put their strategic focus on innovation activities. Research and development investment has therefore become an inexhaustible driving force to enhance competitiveness and ensure the long-term development of enterprises. Innovation requires a lot of human, physical and financial resources. The stability of the external environment of innovation activities is the top priority, which can reduce financing constraints and provide continuous R\&D investment, so as to enhance the core competitiveness of enterprises.

\section{A. It is also feasible to perfect the government's policies and regulations and improve the enthusiasm of enterprises for innovation}

Enterprise innovation cannot be separated from the strong support of the state. The government should strengthen macro-control, attach importance to the formulation of laws and regulations, create a good market environment for enterprises to compete fairly, provide supportive policies and reduce interference in enterprise innovation. At the same time, it should maintain rationality, reduce the one-size-fits-all situation as far as possible, and give full play to the incentive role of the government to achieve the stable development of enterprises.

\section{B. The enterprise's internal rules and regulations should also be improved to strengthen internal control}

An enterprise shall abide by discipline and law and improve its internal rules and regulations, rationally plan its development and operation policies, implement its production and operation activities, formulate policies in accordance with laws and regulations, try its best to avoid getting involved in legal disputes and ensure the stability of the external environment. In addition, the internal control procedures should be 
refined to strictly control the prior review procedures. For example, a resolution of the board or shareholders' meeting should be adopted before a major guarantee contract is signed, rather than individual executives making their own decisions to reduce speculation.

\section{References}

[1] Akçomak, S., \& ter Weel, B. J. (2006). Social capital, innovation and growth: Evidence from Europe.

[2] Acs, Z. J., \& Audretsch, D. B. (1988). Innovation in large and small firms: an empirical analysis. The American economic review, 678-690.

[3] Bushman, R. M., \& Piotroski, J. D. (2006). Financial reporting incentives for conservative accounting: The influence of legal and political institutions. Journal of accounting and economics, 42(1-2), 107-148.

[4] Caggese, A. (2012). Entrepreneurial risk, investment, and innovation. Journal of Financial Economics, 106(2), 287-307.

[5] Chava, S., Oettl, A., Subramanian, A., \& Subramanian, K. V. (2013). Banking deregulation and innovation. Journal of Financial Economics, 109(3), 759-774.

[6] Donelson, D. C., McInnis, J. M., \& Mergenthaler, R. D. (2012). Rules-based accounting standards and litigation. The Accounting Review, 87(4), 1247-1279.

[7] Defond, M. L., \& Hung, M. (2004). Investor protection and corporate governance: Evidence from worldwide CEO turnover. Journal of Accounting Research, 42(2), 269-312.

[8] DuCharme, L. L., Malatesta, P. H., \& Sefcik, S. E. (2004). Earnings management, stock issues, and shareholder lawsuits. Journal of financial economics, 71(1), 27-49.

[9] Francis, J., Philbrick, D., \& Schipper, K. (1994). Shareholder litigation and corporate disclosures. Journal of accounting research, 32(2), 137-164.

[10] Gayle, P. G. (2001). Market concentration and innovation: new empirical evidence on the Schumpeterian hypothesis. University of Colorado at Boulder: unpublished paper.

[11] George, A. (1970). The market for 'Lemons': Quality uncertainty and the market mechanism. Quarterly Journal of Economics, 84(3), 488-500.

[12] Johnson, M. F., Kasznik, R., \& Nelson, K. K. (2001). The impact of securities litigation reform on the disclosure of forward-looking information by high technology firms. Journal of Accounting Research, 39(2), 297-327.

[13] Palmrose, Z. V., Richardson, V. J., \& Scholz, S. (2004). Determinants of market reactions to restatement announcements. Journal of accounting and economics, 37(1), 59-89.

[14] Porta, R. L., Lopez-de-Silanes, F., Shleifer, A., \& Vishny, R. W. (1998). Law and finance. Journal of political economy, 106(6), 1113-1155.

[15] Reinganum, J. F., \& Wilde, L. L. (1986). Settlement, litigation, and the allocation of litigation costs. The RAND Journal of Economics, 557-566.

[16] Rogers, J. L., \& Stocken, P. C. (2005). Credibility of management forecasts. The Accounting Review, 80(4), 12331260 .

[17] Skinner, D. J. (1994). Why firms voluntarily disclose bad news. Journal of accounting research, 32(1), 38-60.

[18] Skinner, D. J. (1997). Earnings disclosures and stockholder lawsuits. Journal of accounting and economics, 23(3), 249-282.

[19] Mao Xinshu, Meng Jie. (2013). Internal Control and Litigation Risk. Management World, 11, 155-165. (in Chinese)
[20] Liu Hui, Zhang Junrui. (2018). Government Intervention, Internal Control and Pending Litigation of Listed Companies. Management Review, 30 (10), 207-220. (in Chinese)

[21] Wei Feng, Xue Fei. (2010). Market Reaction to Promulgation of Laws on Creditor Rights Protection: Based on Study on Theories of Law and Finance. The Study of Finance and Economics, (4), 14. (in Chinese)

[22] Zhang Weiying, Ke Rongzhu. (2002). Reverse Choice in Lawsuits and Its Explanation: An Empirical Study of Written Judgments on Contract Disputes by a Grassroots Court. Social Sciences in China, 2, 31-43. (in Chinese)

[23] Zhu Hengpeng. (2006). Firm Size, Market Power, and the R\&D Behavior of Non-governmental Enterprises, The Journal of World Economy. (in Chinese) 